\title{
Upaya menigkatkan kompetensi guru dalam menyusun rencana pelaksanaan pembelajaran melalui pemberdayaan kegiatan kelompok kerja
}

\author{
Aliasmi $\left.{ }^{*}\right)$ \\ SDN 31 Kumpulan Banang \\ *) Correspondence e-mail: aliasmi@gmail.com
}

\begin{abstract}
The phenomenon in the field illustrates that the existence of the working group or forum has not yet provided a significant contribution to the improvement of teacher competency. Various obstacles faced by teachers, principals, and supervisors currently in an effort to create active and effective activity groups. The purpose of this study is to describe efforts to improve teacher competency in developing learning implementation plans through empowering teacher working group activities. This type of research is the principal's action research. The data analysis technique was analyzed descriptively using the percentage formula. Based on the results of the study it was found that: 1) To improve competence in the learning process carried out through empowering competency activities in the learning process carried out through empowering teacher working group activities on a regular basis as much as 2 cycles, each cycle of 2 meetings, each meeting to make four stages of the planning activities, the implementation of actions, observations and reflections. 2) Observation is carried out by the principal as a collaborator supervisor, ending with reflection to see the positive and negative aspects as a basis for planning the next action in cycle 2. With clinical supervision, there is an increase in teacher competence at the beginning of activities $71.43 \%$ to $93.73 \%$ an increase of $22.30 \%$.
\end{abstract}

Keywords: kompetensi guru, kelompok kerja, penelitian tindakan sekolah

Article History: Received on 07/11/2019 Revised on 29/11/2019; Accepted on 12/12/2019; Published Online: 20/12/2019.

\section{INTRODUCTION}

Pengembangan sumber daya manusia pendidikan, khususnya pengambangan profesionalisme guru, merupakan usaha mempersiapkan guru agar memiliki berbagai wawasan, pengetahuan, keterampilan dan memberikan rasa percaya diri untuk melaksanakan tugas dan kewajibannya sebagai petugas professional. Pengembangan atau peningkatan kemampuan professional harus bertolak pada kebutuhan permasalahan nyata yang di hadapi oleh guru agar bermakna.

Sistem pembinaan professional yang diharapkan ialah suatu pola pembinaan yang mampu meningkatkan dan mendorong guru untuk belajar senatiasa mengembangkan diri untuk meningkatkan keterampilan, kemampuan sikap sehigga memberikan dampak 
2 I Upaya menigkatkan kompetensi guru dalam menyusun rencana pelaksanaan ...

positif dalam melaksanakan kegiatan belajar mengajar yang akhirnya dapat meningkatkan prestasi belajar siswa.

Secara teoritis dan fungsi Kelompok Kerja Guru ( KKG ) merupakan wadah dalam pembinaan professional guru yang dapat dimanfaatkan untuk berkomunikasi, bertukar fikiran dan berbagai pengalaman, melaksanakan berbagai demontrasi, atraksi dan simulasi dalam pembelajaran. Dalam wadah ini para guru dapat membahas permasalahan dari mereka untuk mereka.

Namun fenomena dilapangan tergambar bahwa keberadaan Kelompok Kerja atau forum tersebut keberadaanya belum memberikan konstribusi yang signifikan terhadap peningkatan kompetensi guru. Berbagai kendala yang dihadapi oleh guru, kepala sekolah dan pengawas saat ini dalam usaha menciptakan kelompok kegiatan yang aktif dan efektif adalah usaha berikut: (1). Manajeman kelompok kerja msaih perlu ditingkatkan kualitasnya dalam upaya optimalisasi intesifikasi pembinaan kegiatan kelompok kerja: (2). Program-program kegiatan kelompok kerja masih kurang sesuai dengan kebutuhan pengembangan operasional belum memadai dan kurang dimanfaatkan secara tepat; (4). Bervariasinya perhatian dan konstribusi pemerintah daerah melalui dianas pendidikan terhadap program dan kegiatan kelompok kerja. Oleh karena itu perlu upaya untuk merevitalisasi kelompok kerja tersebut agar aktivitas/kegiatan yang dilakukan oleh kelompok kerja atau forum tersebut dapat memberikan manfaat dalam upaya peningkatan kompetensi guru. Hal tersebut diatas diharapkan dapat memberi konstribusi untuk menumbuh kembangkan budaya pembelajaran yang berpusat pada system instruksional yang prima, sehingga berdampak pada peningkatan kualitas pembelajaran yang berujung pada peningkatan kualitas pendidikan nasional.

Dilihat dari sisi lain kemampuan guru dalam mengembangkan rencana palaksanaan pembelajaran yang digunakan dalam proses pembelajaran seahari-hari masih relatif rendah, RPP hanya sebagai dokumentasi bagi guru, tidak digunakan sesuai prosedur yang sudah mereka buat sebelum proses pembelajaran dilaksanakan, sehinngga tidak tertanam didalam Mind Set guru bahwa RPP sangat penting sebagai pedoman dalam melaksanakan pembelajaran dikelas.

Peranan kepala sekolah untuk mengoptimalkan kegiatan kelompok kerja guru sangat penting, dalam hal ini di setiap pertemuan yang dilakukan harus ada sesuatu yang baru yang didapatkan oleh guru, seperti fenomena di atas masih banyak guru yang masih kurang professional dalam membuat rencana pelaksanaan pembelajaran, dengan ikut serta kepala sekolah membina guru dalal menyusun RPP sesuai dengan prosedur dan stndar yang ada akan meningkatkan kualitas guru terutama dalam menyusun RPP, dan kualitas pembelajaran dapat meningkat.

Berdasarkan permasalahan diatas penulis tertarik untuk malaksanakan sebuah penelitian yang berjudul " upaya meningkatkan komptensi guru dalam menyusun Rencana Pelaksanaan Pembelajaran Melalui Pemberdayaan Kegiatan Kelompok Kerja Guru. 


\section{METHOD}

Jenis penelitian ini adalah penelitian tindakan sekolah (PTS). Penelitian ini dilakukan di UPT SDN 31 Kumpulan Banang Kecamatan Linggo Sari Baganti Kabupaten Pesisir Selatan. Penelitian ini ditujukan kepada semua guru yang ada di UPT SDN 31 Kumpulan Banang sejumlah sebanyak 16 orang. Langkah-langkah PTS yaitu: perencanaan, pelaksanaan, pengamatan,dan refleksi. Teknik pengumpulan data dilakukan dengan cara pengisian lembaran observasi salam proses tendakan penelitian oleh supervisor sehingga akan diperoleh data kualitatif sebagai hasil penelitian. Instrument penelitian yang akan digunakan adalah lembaran observasi yang digunakan oleh supervisor untuk mencatat perkembangan kemampuan masing-masing guru yang dibinanya selama proses penelitian (siklus 1 dan siklus 2). Lembar observasi yang digunakan dalam penelitian ini. Tenik analisis data dilakukan terhadap hasil motivasi kerja guru sebagai data awal kemampuan guru dan hasil observasi yang dilakukan selama proses pembinaan akan di analisis secara deskriptif untuk mengukur keberhasilan proses pembinaan sesuai dengan tujuan penelitian tindakan sekolah ini.

Analisis data dilakukan terhadap data yang telah diredukasi baik data perencanaan, pelaksanaan, maupun data evaluasi. Analisis data ini dilakukan dengan cara terpisah-pisah, hal ini dilakukan agar dapat ditemukan berbagai informasi yang spesifik dan terfokus pada bebagai informasi yang mendukung pembelajaran dan mengahambat pembelajaran. Data tentang aktifitas observasi kegiatan yang dilakukan guru dihitung dengan rumus persentase Sudijono (2011:43).

\section{RESULTS AND DisCUSSION}

Penelitian ini adalah penelitian tindak sekolah (PTS) yang telah dilaksanakan secara berkolaboratif seluruh guru kelas di UPT SDN 31 Kumpulan Banang Kecamatan Linggo Sari Baganti Kabupaten Pesisir Selatan. Hasil dan pembahasan dari pelaksanaan penelitian tindakan sekolah ini akan dipaparkan sebagai berikut :

\section{Hasil Penelitian}

Penelitian tindakan sekolah ini dilaksanakan dalam 2 siklus, bedasarkan wawancara penulis dengan beberapa orang guru di UPT SDN 31 Kumpulan Banang Kecamatan Linggo Sari Baganti Kabupaten Pesisir Selatan banyak guru-guru yang belum mampu dalam penyusunan rencana pelaksanaan pembelajaran dengan efektif. Berikut ini sesuai dengan perencanaan yag disusun dengan tahapan sebagai berikut:

\section{Siklus I}

Perencanaan. Pada tahap perncanaan penelitian menyusun rencana pelaksanaan perbaikan dengan membagi guru dalam beberapa kelompok untuk mempersiapkan format dan instrument lainnya. observasi yang diperlukan dalam penelitian ini adalah penelitian dilaksanakan di masing-masing Kelompok Kerja Guru (KKG) yang nantinya kepala sekolah akan memberikan dan bimbingan dari aspek apa saja guru yang masih lemah dalam penyusunan rencana pelaksanaan pembelajaran nantinya.

Pelaksanaan. Pelaksanaan penelitian tindakan sekolah ini dilakukan di UPT SDN 31 Kumpulan Banang Kecamatan Linggo Sari Baganti Kabupaten Pesisir Selatan yang 
4 I Upaya menigkatkan kompetensi guru dalam menyusun rencana pelaksanaan ...

dilaksanakan pada bulan September 2019 berkaitan dengan usaha peningkatan kompetensi guru kepala sekolah sudah melaksanakan program pemberdayaan kegiatan keolmpok kerja guru. Kepala sekolah mengoservasi kelas secara lansung dan mengamati cara guru mengajar. Apakah guru sudah menguasai meteri atau belum, mengamati media dan metode yang diguanakan .Disamping ini kepala sekolah memiliki program lain yaitu diadakan diskusi kelaompok, KKG, rapat guru melihat RPP dan silabus.

Kegiatan diawali dengan mendiskusikan tetang permasalahan yang dihadapi dalam menyusun RPP melalui kelompok yang dilanjutkan dengan penyampaian informasi tetang cara menyusun RPP serta memebrikan contoh model menyususn RPP yang baik sesuai dengan prosedur yang telah ditentukan dan sesuai dengan standar yang sudah ada. Masing - masing kelompok mengakaji contoh model menyusun system penilaian yang diberikan, kemudian menetapkan format menyususn sistem penilaian yang digunakan. Setelah menyepakati format yang digunakan guru melalui sistem menyusun sistem penilaian dalam kelompok sekolah masing-masing.

Pengamatan. Hasil pengamatan observasi berkaitan dengan kompetensi guru dalam menyusun perencanaan pembelajaran melalui pemberdayaan kegiatan kelompok kerja guru

\begin{tabular}{|c|c|c|c|c|c|}
\hline \multirow{2}{*}{ No } & \multirow{2}{*}{ Aspek yang diobservasi } & \multicolumn{2}{|c|}{ Pertemuan I } & \multicolumn{2}{|c|}{ Pertemuan 2} \\
\hline & & Jumlah & Persentase & Jumlah & Persentase \\
\hline 1 & $\begin{array}{l}\text { Ketersediaan dan Kelengkapan } \\
\text { Silabus }\end{array}$ & 9 & $64.29 \%$ & 11 & $78.57 \%$ \\
\hline 2 & $\begin{array}{l}\text { Ketersediaan dan Kelengkapan } \\
\text { RPP }\end{array}$ & 7 & $50.00 \%$ & 8 & $57.14 \%$ \\
\hline 3 & $\begin{array}{l}\text { Ketersediaan dan Kelengkapan } \\
\text { Bahan Ajar }\end{array}$ & 6 & $42.86 \%$ & 9 & $64.29 \%$ \\
\hline 4 & $\begin{array}{l}\text { Ketersediaan dan Kelengkapan } \\
\text { Instrumen Evaluasi }\end{array}$ & 7 & $50.00 \%$ & 10 & $71.43 \%$ \\
\hline 5 & $\begin{array}{l}\text { Ketersedian Program } \\
\text { Pendukung }\end{array}$ & 10 & $71.43 \%$ & 12 & $85.71 \%$ \\
\hline & Jumlah & \multicolumn{2}{|c|}{$278,57 \%$} & \multicolumn{2}{|c|}{$357,14 \%$} \\
\hline & Rata-rata & \multicolumn{2}{|c|}{$55,71 \%$} & \multicolumn{2}{|c|}{$71,43 \%$} \\
\hline
\end{tabular}

Tabel di atas bedasarkan hasil observasi dilihat dari ketersediaan dalam dan kelengkapan silabus terlihat pada petermuan 1 sebanyak 9 orang $(64,29 \%)$ sedangkan pada pertemuan 2 sebanyak 11 orang $(78,57 \%)$ dalam hal ini tidak terjadi peningkatan kemampuan guru dalam melengkapi silabus, kemampuan guru dalam melengkapi RPP sudah termasuk dalam kategori baik yaitu pada pertemuan 1 sebanyak 7 orang $(50,00 \%)$ sedangkan pada pertemuan 2 tidak terjadi peningkatan yaitu masih sebanyak 8 orang $(57,14 \%)$. 
Pada aspek ketersediaan guru pada bahan ajar pada pertemuan 1 sebanyak 6 orang (42,86\%) sedangkan pada pertemuan 2 sebanyak 9 orang $(64,29 \%)$ dalam aspek ini terjadi peningkatan kemampuan guru dalam aspek ketersediaan guru pada bahan ajar sebanyak $21,43 \%$.

Aspek ketersedian dan kelengkapan instrument evaluasi pada pertemaun 1 sebanyak 7 orang (50,00\%), pada pertemuan 2 sebanyak 10 orang $(71,43 \%)$. Pada aspek ketersedian guru pada program pendukung pertemuan 1 sebanyak 10 orang (71,43\%) terlihat pada pertemuan 2 sebanyak 12 orang $(85,71 \%)$, dalam hal ini terjadinya peningkatan kemampuan guru dalam program pendukung.

Refleksi. Pelaksanaan kegiatan belajar mengajar pada siklus 1 masih terdapat kekurangan, sehingga perlu adanya revisi untuk dilakukan pada siklus berikutnya. Kesulitan yang dilakukan guru adalah pada aspek 1) ketersediaan dan kelengkapan silabus, 2) ketersediaan dan kelengkapan RPP, 3) ketersediaan dan kelengkapan Instrumen Evaluasi. Hasil penilitian menunjukan hanya pada aspek kelengkapan bahan ajar dan ketersediaan program pendukung yang mengalami peningkatan. Namun hasil yang diharapkan belum dapat tercapai pada siklus 1 ini maka akan dilanjutkan pada siklus II.

\section{Siklus II}

Pada siklus II kegiatan yang dilakukan adalah melakukan kegiatan penyempurnaan KKG yang dapat memperbaiki perecanaan pembelajaran guru dan melakukan refleksi dan evaluasi. Penelitian memberikan pengarahan dan bimbingan sesuai hasil observasi yang dilaksanakan pada siklus 1 dimana aspek-aspek apa saja yang perlu ditingkatkan sehingga kompetensi guru dapat meningkatkan sesuai dengan apa yang diharapkan. Untuk lebih jelas dapat diuraikan sebagai berikut:

Perencanaan. Perencanaan penilitian siklus II ini tidak jauh berbeda dengan siklus I yang telah dilakukan diatas, namun pada siklus II ini peneliti atau kepala sekolah tetap menyediakan lembar observasi berkaitan dengan proses pembinaan yang dilakukan sesuai dengan jadwal yang telah ditentukan sebelumnya, sebelum melakukan observasi kepala sekolah terlebih dahulu memberi tahu kepada guru yang bersangkutan bahwa observasi akan dilaksanakan pada tanggal dan jam yang telah ditentukan, sehingga guru dapat mempersiapkan diri sebelumnya.

Pelaksanaan. Pelaksanaan dilakukan setelah lembar observasi disusun dan dipersiapkan, proses pembibingan dilakukan dengan tujuan meningkatkan kompetensi guru di dalam proses pembelajaran, sehingga guru lebih termotivasi dalam mengajar. Dalam proses pelaksanaan penelitian tentunya tidak semua guru dapat menangkap apa yang telah diberikan proses pembibingan, namun begitu peneliti yang berperan sebagai kepala sekolah mempunyai kewajiban dan tanggung jawab dalam membina semua guru-guru terutama dalam proses pembelajaran. Pelaksanaan kegiatan belajar mengajar untuk siklus II dilaksanakan pada bulan September 2019 di UPT SDN 31 Kumpulan Banang Kecamatan Linggo Sari Baganti Kabupaten Pesisir Selatan dengan jumlah guru sebanyak 16 orang.

Kegiatan diawali dengan mendiskusikan tentang permasalahan yang dihadapi dalam menyusun RPP serta memberikan contoh model penyususnan RPP yang baik 
sesuai dengan prosedur yang telah ditentukan dan sesuai dengan standar yang sudah ada. Masing-masing kelompok mengkaji contoh model menyusun sistem penilaian yang diberikan, kemudian menetapkan format menyusun sistem penilaian yang digunakan. Setelah menyepakati format yang digunakan guru ,mulai menyusun sistem penilaian dalam kelompok sekolah masing-masing.

Observasi. Setelah dilakukan pembinaan kepada guru-guru sesuai dengan permasalahan yang ditentukan di lapangan kemudian kepala sekolah masuk ke dalam kelas kembali dengan tujuan malakukan observasi berdasarkan pembinaan yang dilakukan, kepala sekolah sudah menyiapkan lembar observasi sesuai dengan proseduran yang telah ditetapkan.

Dari hasil observai terhadap sikap guru pada siklus II banyak mengalami perubahan bahkan guru lebih meningkatkan kerja samanya. Hasil observasi siklu II dapat disajikan sebagai berikut.

\begin{tabular}{|c|c|c|c|c|c|}
\hline \multirow{2}{*}{ No } & \multirow{2}{*}{ Aspek yang diobservasi } & \multicolumn{2}{|c|}{ Pertemuan I } & \multicolumn{2}{|c|}{ Pertemuan 2} \\
\hline & & Guru & Persentase & Guru & Persentase \\
\hline 1 & $\begin{array}{l}\text { Ketersediaan dan Kelengkapan } \\
\text { Silabus }\end{array}$ & 14 & $87.50 \%$ & 16 & $100.00 \%$ \\
\hline 2 & $\begin{array}{l}\text { Ketersediaan dan Kelengkapan } \\
\text { RPP }\end{array}$ & 13 & $81.25 \%$ & 15 & $93.75 \%$ \\
\hline 3 & $\begin{array}{l}\text { Ketersediaan dan Kelengkapan } \\
\text { Bahan Ajar }\end{array}$ & 11 & $68.75 \%$ & 13 & $81.25 \%$ \\
\hline 4 & $\begin{array}{l}\text { Ketersediaan dan Kelengkapan } \\
\text { Instrumen Evaluasi }\end{array}$ & 15 & $93.75 \%$ & 15 & $93.75 \%$ \\
\hline 5 & $\begin{array}{l}\text { Ketersedian Program } \\
\text { Pendukung }\end{array}$ & 16 & $100.00 \%$ & 16 & $100.00 \%$ \\
\hline & Jumlah & & $431,25 \%$ & & $468,75 \%$ \\
\hline & Rata-rata & & $86,25 \%$ & & $93,75 \%$ \\
\hline
\end{tabular}

Table diatas bedasarkan hasil obeservasi dilihat dari ketersediaan dan kelengkapan selabus pada pertemuan 1 sebanyak 14 orang (87.50\%) sedangkan pada pertamuan 2 masih sebanyak 16 orang $(100 \%)$ dalam hal ini terjadi peningkatan kemampuan guru dalam kategori sangat baik yaitu pada pertemuan 1 sebanyak 13 orang $(81,25 \%)$ sedangkan pada pertemuan 2 terjadi peningkatan yaitu sebanyak 15 orang (93,75\%).

Pada aspek ketersediaan guru pada bahan ajar pada pertemuan 1 sebanyak 11 orang $(68,75 \%)$ sedangkan pada pertemuan 2 sebanyak 13 orang $(81,25 \%)$ dalam aspek ini terjadi peningkatan kemampuan guru dalam aspek ketersediaan guru dalam aspek ketersediaan guru pada bahan ajar sebanyak $12.50 \%$ dan termasuk dalam kategori sangat baik. 
Aspek ketersediaan dan kelengkapan instrument evaluasi pada pertemuan 1 sebanyak 15 orang $(93,75 \%)$, pada pertemuan 2 sebanyak 15 orang $(93,75 \%)$. Pada aspek ketersediaan guru pada program pendukung terlihat pada pertemuan 1 sebanyak 16 orang $(100 \%)$ sedangkan pada pertemuan 2 sebanyak 16 orang $(100 \%)$, dalam hal ini terjadi peningkatan kemampuan guru dalam pada program pendukung.

Refleksi. Memperhatikan hasil pada siklus II melakukan refleksi terhadap hasil yeng diperoleh penelitian pada siklus II ini sudah baik dan tidak ditemukan lagi kekurangankekurangan guru dalam proses pembelajaran, namun penelitian tidak mengungkiri bahwa masih ada beberapa guru yang belum melakukan perubahan yang signifikan, bedasarkan hasil penelitian yang dilakukan apa yang diharapkan sudah sesuai dengan apa yang telah direncanakan sebelumnya, sehinga penelitian ini dihentikan pada siklus II.

\section{Pembahasan}

Hasil penelitian membuktikan bahwa terdapat peningkatan kompetensi guru dalam proses pemebelajaran dimana berdasarkan hasil observasi yang dilakukan terdapat peningkatan kompetensi guru bedasarkan pembelajaran melalui pemberdayaan kegiatan kelopmpok kerja guru di UPT SDN 31 Kumpulan Banang Kecamatan Linggo Sari Baganti Kabupaten Pesisir Selatan.

Guru memiliki pengaruh luas dalam dunia pendidikan. Di sekolah dia adalah pelaksana administrasi pendidikan yaitu bertanggung jawab agar pendidikan dapat berlansung dengan baik. Guru wajib memiliki kualitas akademi, kompetensi, sertifikat pendidikan, sehat jasmani dan rohani, serta memiliki kemampuan untuk mewujudkan tujuan pendidikan nasional.

Istilah kompetensi berasal dari interest. Dalam kemus bahasa Inggris Indonesia, kompetensis berate wewenang. Menurut Majid (2005:6) menjelaskan kompetensi yang dimiliki oeleh setiap guru akan mengujudkan kualitas guru dalam mengajar. Kompetensi tersebut akan terwujud dalam menjalakan fungsinya sebagai guru. Sejalan dengan itu Mulyasa (2006:38) mengartikan kompetensi sebagai penguasaan terhadap suatu tugas ketrampilan, sikap, dan apresiasi yang diperlukan untuk menunjang keberhasilan. Sofo (1999:123) mengemukakakn "A competency is composed of skill,knowledge, and attitude, but to the standard of performance required in employment", dengan kata lain kompetensi tidak hanya mengandung pengetahuan keterampilan, dan sikap, namun yang penting adalah penerapan dari pengetahuan, ketrampilan, dan sikap yang diperlukan tersebut dalam pekerjaan.

Kompetensi sebagai ability, yaitu kapasitas seorang individu untuk mengerjakan berbagai tugas dalam suatu pekerjaan. Selajutnya dikatakan bahwa kemampuan individu dibentuk oleh dua factor, yaitu factor kemampuan intelektual dan kemampuan fisik. Kemampuan intelektual adalah kemampuan yang diperlukan untuk melakukan kegiatan mental sedangkan kemampuan fisik adalah kemampuan yang diperlukan untuk melakukan tugas-tugas yang menutut stamina, kecekatan, kekuatan, dan ketrampilan. Selanjutnay Mulyasa (dalam Musfah.2011:27) bahwa kompetensi guru merupakan perpaduan antara kemempuan personal, keilmuan,teknologi,social,dan spiritual yang secara kafah membentuk kompetensi standar profesi guru. 


\section{CONCLUSIONS}

Berdasarkan hasil penelitian dan pembahasan yang telah diuraikan secara lengkap pada bab sebelumnya dapat ditarik kesimpulan sebagai berikut : 1) Untuk meningkatkan kompetensi dalam proses pembelajaran dilakaukan melalaui pemberdayaan kegiatan kelompok kerja guru secara berkala sebanyak 2 siklus, tiap siklus 2 kali pertemuan, tiap pertemuan melakukan 4 tahap kegiatan yang dimulai dari perencanaan, pelaksanaan tindakan, pengamatan dan refleksi; 2) Observasi dilakukan kepala sekolah sebagai kolaborator pengawas, diakhiri dengan refleksi untuk melihat segi positif dan negative sabagai landasan perencanaan tidakan berikutnya pada siklus 2. Dengan supervise klinis terjadi peningkatan kompetensi guru pada awal kegiatan $71.43 \%$ menjadi $93.73 \%$ terjadi peningkatan sebasar $22,30 \%$.

\section{REFERENCES}

Bafal,I. 2003. Peningkatan Profesionalisme Guru. Jakarta : Bumi Aksara

Bolligton, R. Hopkins, D., \& West, M. 1990. An Introduction to Teacher Appraisal. London

Cassell, Brown. G.Alih Bahasa Laurens K. 1991. Pengajaran Mikro, Program Keterampilan Mengajar. Surabaya : Erlanga

Cece Wijaya, dkk. Upaya Pembaharuan Dalam Pendidikan Dan pengajaran. Bandung: Rineka Cipta

Mulyasa. 2008. Menjadi Guru Profesional, Menciptakan Pembelajaran Kreatif dan Menyenangkan. Bandung: Remaja Rodakarya

E. Mulyasa. 2007. Standar Kompetensi dan Sertifikasi Guru. (Bandung: Remaja Rosdakarya

Hamzah B. Uno.2007. Profesi Kependidikan (Problem, solusi dan reformasi Indonesia. Jakarta: Bumi Aksara

Hasibuan \& Moedjiono. 2004. Proses Belajar Mengajar. Bandung : Remaja Rosda karya

Moh. User Usman. 2005. Menjadi Guru Profesional. (Bandung: PT Remaja Rosdakarya Remaja Rosdakarya.

Syaiful Sagala. 2009. Kemampuan Profesional Guru dan tenaga kependidikan, Bandung: Alfabeta.

Trianto, dkk. 2006. Tinjauan Yuridis Hak serta Kewajiban Pendidikan Menurut UU Guru dan Dosen. Jakarta: Persentasi Putaka

Undang-Undang Sistem Pendidikan Nasional No. 20 tahun 2003, Bandung: Citra utama 